\title{
CYFROWY JEDWABNY SZLAK I WZRASTAJACE ZNACZENIE CHIŃSKIEJ REPUBLIKI LUDOWEJ W RYWALIZACJI O TECHNOLOGICZNE PRZYWÓDZTWO NA ŚWIECIE
}

\section{Wstęp}

W ciagu ostatnich kilku lat wielu naukowców przeanalizowało chińską Inicjatywę Pasa i Szlaku, ale bardzo niewielu badało znaczacy element tej inicjatywy - Cyfrowy Jedwabny Szlak (Digital Silk Road, DSR) ${ }^{1}$. Choć uwaga dotycząca inicjatywy Belt and Road skupiona jest głównie na realizacji międzynarodowych projektów infrastruktury transportowej, takich jak drogi, koleje czy porty, to istotne wydaje się zwrócenie uwagi na technologiczny komponent tego projektu. Może mieć on ogromne konsekwencje gospodarcze, technologiczne, społeczne i polityczne dla bezpieczeństwa państw na całym świecie. Wysiłki technologiczne Chin mają na celu wzmocnienie międzynarodowego przywództwa i zdolności Państwa Środka w zakresie nowych technologii, które wspierają i łączą wiele innych głównych celów Chin w ramach ich wielkiej strategii.

Głównym celem artykułu jest przedstawienie informacji na temat Cyfrowego Jedwabnego Szlaku oraz zbadanie chińskich działań w tym zakresie. Należy podkreślić, że wczesna faza rozwoju, a mianowicie planowanie Inicjatywy Pasa i Szlaku²,

ORCID: 0000-0003-0583-0938, DOI: 10.4467/23538724GS.20.053.13493

1 Autorka zamiennie stosuje pojęcia: Cyfrowego Jedwabnego Szlaku, Digital Silk Road oraz DSR, uważając je za tożsame. W Polsce tematyką Inicjatywy Pasa i Szlaku zajmują się m.in. Jacek Bartosiak, Bogdan Góralczyk, Łukasz Gacek, Marcin Kaczmarski, Tomasz Morozowski, Adam Nobis, Ewa Oziewicz, Joanna Szczudlik-Tatar. Jednakże, jeżeli mowa o artykułach na temat Cyfrowego Jedwabnego Szlaku, w polskiej literaturze przedmiotu jest na ten temat bardzo niewiele, a zagadnienie to opisała M. Majcherczyk, Cross-border e-commerce wzdluž Cyfrowego Jedwabnego Szlaku, „Gdańskie Studia Azji Wschodniej” 2018, z. 14, s. 70-86. W czasopismach zagranicznych poruszali tę tematykę m.in.: G. Huadong $\mathrm{i}$ in., The Digital Belt and Road program in support of regional sustainability, „International Journal of Digital Earth” 2018, vol. 11, no. 7; H. Shen, Building a digital silk road? Situating the internet in China's belt and road initiative, „International Journal of Communication" 2018, vol. 12. Z racji rozwoju inicjatywy i jej cyfrowego komponentu nadal jest mało prac ujmujących ten obszar badawczy w sposób kompleksowy.

2 Aktualny i przyszły rozwój inicjatywy można podzielić na trzy fazy: faza 1: mobilizacja (2013-2016), faza 2: planowanie (2016-2021) oraz faza 3: realizacja (2021-2049). Zob. szerzej: P. Tomaszewska, Dilemmas related to the Poland's participation in the Chinese Belt and Road Initiative, „Przegląd Strategiczny” 2019, nr 12, s. 161-179. 
jak również Cyfrowego Jedwabnego Szlaku budzi wiele pytań. Czym jest Cyfrowy Jedwabny Szlak? Jakie działania podjęto w celu jego realizacji? Jakie wyzwania i zagrożenia może on generować? Czy Cyfrowy Jedwabny Szlak przyczyni się w jeszcze większym stopniu do wyeksponowania wzrastającej technologicznej roli Chin na świecie? W zauważalny sposób Chiny wykorzystują nowe technologie komunikacyjne, zwłaszcza 5G, do budowy globalnej autostrady technologicznej. Analiza strategicznych założeń inicjatywy pozwala stwierdzić, że Pekin promuje własne standardy, własne firmy i własne rozwiązania cyfrowe, stanowiące narzędzia do wywierania wpływu na zagraniczne elity polityczne i biznesowe.

Niewatpliwie Cyfrowy Jedwabny Szlak, będący platformą promująca rozwój połączeń cyfrowych pomiędzy krajami uczestniczącymi w inicjatywie, może pomóc w rozpowszechnieniu chińskich ,wynalazków - produktów” cyfrowych ${ }^{3}$. Ponadto może przyczynić się do ułatwienia rozwoju gospodarczego i społecznego państw leżących wzdłuż Cyfrowego Jedwabnego Szlaku, poprawiając tym samym poziom rozwoju gospodarczego państw beneficjentów oraz generując nowe międzynarodowe przewagi konkurencyjne ${ }^{4}$. Cyfrowy Jedwabny Szlak jest niezbędny dla zbudowania chińskiej cyfrowej potęgi na świecie, a wobec tego pozostaje aktualnym $\mathrm{i}$ bardzo istotnym obszarem badawczym. W dzisiejszych czasach epicentrum innowacji znajduje się w Dolinie Krzemowej. Jednakże wydaje się, że w przyszłości prawdopodobnie Chiny staną się głównym kreatorem, a także najważniejszym uczestnikiem światowego technologicznego wyścigu. Chińczycy, częstokroć określani jako naśladowcy, szybko rozwijaja się i zmierzają w kierunku nazywania ich liderami w dziedzinie innowacji. Zdolność adaptacyjna, zwinność i hiperkonkurencyjność chińskich firm już doprowadziły do ważnych nowych osiagnięć oraz innowacyjnych modeli biznesowych ${ }^{5}$. W artykule posłużono się analizą danych zastanych (desk research) na temat zmieniającej się pozycji Chińskiej Republiki Ludowej w rywalizacji o technologiczne przywództwo na świecie, a także konsekwencji, jakie to ze sobą niesie.

\section{Działania ChRL przyczyniające się}

do wzrostu znaczenia jej możliwości cyfrowych

Chiny podejmują wiele działań, aby wyeksponować swój potencjał technologiczny. W 2015 r. chińska partia wprowadziła „Made in China 2025” - politykę przemysłową mającą na celu rozszerzenie chińskiego sektora technologicznego i zaawansowanych zdolności produkcyjnych poprzez dotacje państwowe, nabywanie własności

3 K. Fung, N. Aminian, X. Fu, Ch. Tung, Digital Silk Road, Silicon Valley and connectivity, ,Journal of Chinese Economic and Business Studies" 2018, vol. 16, no. 3, s. 331.

4 H. Liang, Y. Zhang, The theoretical system of belt and road initiative, Singapore 2019, s. 39.

5 K. Fung, N. Aminian, X. Fu, C. Tung, Digital Silk Road..., s. 325-326. 
intelektualnej i zagraniczne spółki joint venture, które miały prowadzić do transferów wiedzy i know-how ze spółek zagranicznych ${ }^{6}$. Ostatecznym celem było zmniejszenie zależności Chin od zagranicznych technologii i globalna promocja chińskiej produkcji technologicznej ${ }^{7}$. W ciagu kilku lat od ogłoszenia „Made in China 2025” i „Cyber Superpower Strategy” Chiny wyprodukowały dziesiątki technologicznych ,jednorożców” (prywatne firmy typu startup o wartości powyżej 1 mld USD). W 2020 r. ogłosiły swój kolejny projekt China Standards 2035 - wizję wpływania na przyszłe międzynarodowe standardy technologiczne i interoperacyjność ${ }^{8}$. Także Biuro Centralnej Komisji ds. Cyberprzestrzeni po wezwaniu Xi Jinpinga, by Chiny stały się „cyber-supermocarstwem”, jako część swoich działań przedstawiło plan wzrastającego udziału chińskich gigantów technologicznych w światowym rynku oraz rozprzestrzenianie się chińskich standardów ${ }^{9}$. Istotna wydaje się też chociażby analiza Narodowej strategii dot. informatyzacji Rady Państwa (2016-2020), w której wezwano chińskich prywatnych gigantów technologicznych gospodarki cyfrowej, takich jak: Alibaba, Tencent i Baidu, do wspierania rozwoju Cyfrowego Jedwabnego Szlaku ${ }^{10}$. Te strategiczne dokumenty pokazuja, że inwestycja Komunistycznej Partii Chin (KPCh) w sektor technologiczny nie polega jedynie na jej własnym rozwoju gospodarczym lub polityce handlowej ${ }^{11}$.

Pod pewnymi względami czynniki pandemiczne i geopolityczne, takie jak trwajace napięcia między USA i Chinami, miały negatywny wpływ na realizację chińskich założeń. Zmniejszyły chęci zagranicznych firm do współpracy z Chinami i zwiększyły ostrożność oraz dystans w kwestii zawierania umów ${ }^{12}$. Niemniej pandemia przyczyniła się także w sposób pozytywny dla promocji chińskich produktów cy-

6 P. Paszak, Chinskie ambicje w sektorze pótprzewodnikón, Warsaw Institute, https://warsawinstitute.org/pl/chinskie-ambicje-w-sektorze-polprzewodnikow/ (dostęp: 10.01.2021).

7 J. McBride, A. Chatzky, Is 'Made in 2025' a Threat to Global Trade?, „Council on Foreign Relations", 13.05.2019, https://www.cfr.org/backgrounder/made-china-2025-threat-global-trade (dostęp: 10.01.2021).

8 A. Kharpal, Power is 'Up for Grabs': Behind China's Plan to Shape the Future of Next-generation Tech, CNBC, 26.04.2020, https://www.cnbc.com/2020/04/27/china-standards-2035-explained. html (dostęp: 10.01.2021).

9 E. Kania, S. Sacks, P. Triolo, G. Webster, China's Strategic Thinking on Building Power in Cyberspace, „New America”, 25.09.2017, https://www.newamerica.org/cybersecurity-initiative/blog/ chinas-strategic-thinking-building-power-cyberspace/ (dostęp: 10.01.2021).

10 国务院关于印发“十三五”国家信息化规划的通知国发号, http://www.gov.cn/ zhengce/ content/2016-12/27/content_5153411.htm (dostęp: 10.01.2021).

11 A. Polyakova, C. Meserole, Exporting Digital Authoritarianism: the Russian and Chinese Models, Brookings Institution, 7.08.2019, https://www.brookings.edu/research/exporting-digital-authoritarianism/ (dostęp: 10.01.2021).

12 E. Zhang, How Will the Coronavirus Impact Xi's Made in China 2025' Plan?, „Medium”, 12.05.2020, https://medium.com/wonk-bridge/how-will-the-coronavirus-impact-xis-made-inchina-2025-plan-db55c31c6f4a (dostęp: 11.01.2021). 
frowych. Nastapiło rozszerzenie krajowego nadzoru cyfrowego KPCh i rozwoju sztucznej inteligencji, a także eksportu tej technologii. To z kolei promowało chińskie cyfrowe normy, technologię i metody sztucznej inteligencji jako narzędzia kontroli politycznej i społecznej na świecie ${ }^{13}$.

Chińskie firmy technologiczne są wiodącymi twórcami różnych narzędzi do monitorowania, które pomagają w cenzurze i inwigilacji. Za pośrednictwem popularnych aplikacji rząd wykorzystuje te technologie do monitorowania osób i blokowania dostępu do usług i komunikacji14. Chiny mają największe na świecie sieci monitoringu. Składaja się one z wielu lokalnych sieci ponad $200 \mathrm{mln}$ kamer telewizji przemysłowej (CCTV) w przestrzeniach publicznych w całym kraju, wyposażonych przez różne firmy, które dostarczają dane władzom za pośrednictwem takich programów, jak SkyNet ${ }^{15}$. Aplikacja ta gromadzi np. obrazy ze skrzyżowań czy miejsc zgromadzeń publicznych. Mapuje je za pomoca systemu informacji geograficznej (GIS) w celu usprawnienia monitorowania w czasie rzeczywistym. Program jest promowany przez rząd jako inicjatywa ,inteligentnego miasta" i mechanizm ułatwiający przeciwdziałanie przestępczości. Co ciekawe, sukces SkyNet zapoczątkował jeszcze szerszą inicjatywę nadzoru, Sharp Eyes, której celem jest podłączenie kamer w „Internecie”, np. w smartfonach, pojazdach, telewizorach i urządzeniach z kamerami monitorującymi. Wdrożony początkowo na obszarach wiejskich, gdzie zasięg KPCh jest mniejszy, Sharp Eyes sprawia, że monitorowanie jest jeszcze bardziej rozległe i precyzyjne ${ }^{16}$. Dla przykładu, Ujgurowie internowani w prowincji Xinjiang jako pierwsi poczuli pełną wagę możliwości masowej inwigilacji KPCh, wspomaganej technologia dostarczaną przez firmy specjalizujące się w rozpoznawaniu twarzy $i$ analizie tłumu. Jednakowoż ambicje w zakresie nadzoru wykraczają poza Xinjiang ${ }^{17}$.

Chiny stosuja zarówno pasywne, jak i aktywne środki, aby eksportować swoja reakcję nadzoru opartą na technologii. Środki, które niegdyś były uważane za skrajne wśród nieautorytarnych rządów i społeczeństw, stały się bardziej znormalizowane, gdy pandemia ogarnęła cały świat. W większym stopniu odrzucono obawy dotyczące prywatności w interesie bezpieczeństwa publicznego oraz stanu zdrowia

13 J. Lanier, G. Weyl, AI is an Ideology Not a Technology, ,Wired”, 15.03.2020, https://www.wired. com/story/opinion-ai-is-an-ideology-not-a-technology/ (dostęp: 11.01.2021).

14 S. McDonell, China Social Media: We Chat and the Surveillance State, „BBC News”, 7.06.2019, https://www.bbc.com/news/blogs-china-blog-48552907 (dostęp: 11.01.2021).

15 P. Mozur, Inside China's Dystopian Dreams: AI, Shame and Lots of Cameras, „The New York Times", 8.07.2018, https://www.nytimes.com/2018/07/08/business/china-surveillance-technology.html (dostęp: 11.01.2021).

16 J. Rudolph, Sharper Eyes: Surveilling the Surveillers (Part 1), „China Digital Times”, 9.09.2019, https://chinadigitaltimes.net/2019/09/sharper-eyes-surveilling-the-surveillers-part-1/ (dostęp: 12.01.2021).

17 P. Mozur, One Month, 500,000 Face Scans: How China is Using AI to Profile a Minority, „The New York Times", 14.04.2019, https://www.nytimes.com/2019/04/14/technology/china-surveillance-artificial-intelligence-racial-profiling.html (dostęp: 12.01.2021). 
obywateli. Oczywiście Chiny nie są jedynymi, którzy korzystają z nadzoru i innych technologii do śledzenia i monitorowania obywateli w celu powstrzymania epidemii wirusów. Izrael, Tajwan, Indie, Korea Południowa, Australia, Polska i inne kraje wdrożyły aplikacje do śledzenia osób chorych na COVID-19 i użyły dronów, lokalizatorów telefonów komórkowych oraz analizy transakcji finansowych do monitorowania przestrzegania kwarantanny i rozprzestrzeniania się wirusa.

Wydaje się więc, że chociaż Chiny zanotowały pierwszy od dziesięcioleci kryzys gospodarczy w 2020 r., ich strategia cyber-supermocarstwa pozostaje na dobrej drodze. Państwo to nadal intensywnie inwestuje w technologie 5G, infrastrukture nadzoru, sztuczną inteligencję i swój sektor technologiczny za pośrednictwem chińskiego funduszu New Infrastructure Investments Fund w ramach ożywienia gospodarczego po pandemii ${ }^{18}$. Mocno finansowany przez państwo sektor technologii służy chińskiej polityce zagranicznej i narodowym strategiom bezpieczeństwa. Jednakże niepokojący jest fakt, że wiele firm technologicznych jest ściśle powiązanych z chińskim wywiadem i aparatem bezpieczeństwa narodowego ${ }^{19}$.

\section{Czym jest Cyfrowy Jedwabny Szlak?}

Podczas gdy do tej pory w ramach Belt and Road realizowano w głównej mierze tradycyjne projekty infrastrukturalne, coraz częściej można usłyszeć o kolejnym jego komponencie, czyli Cyfrowym Jedwabnym Szlaku. Termin ten został wprowadzony w 2015 r. w oficjalnej Białej Księdze chińskiego rządu. Jest on uzupełnieniem wspomnianej wcześniej strategii „Made in China 2025”, mającej dać ChRL prymat w sferze nowoczesnych technologii ${ }^{20}$. W marcu 2015 r. Chińska Narodowa Komisja Rozwoju i Reform, Ministerstwo Spraw Zagranicznych i Ministerstwo Handlu wspólnie wydały swój pierwszy oficjalny plan BRI i specjalnie wezwały do stworzenia informacyjnego Jedwabnego Szlaku ${ }^{21}$. W 2016 r. Rada Stanu wydała 13. pięcioletni plan informatyzacji kraju, skupiający się na budowie DSR i zachęcaniu chińskich firm internetowych do udziału w programie ${ }^{22}$.

18 J. Cohen, The World Relies on China's Surveillance Technology, „PC Magazine”, 13.12.2019, https://au.pcmag.com/news/64899/the-world-relies-on-chinas-surveillance-technology (dostęp: 13.01.2021).

19 C. Balding, D. Clarke, Who Owns Huawei?, „Social Science Research Network”, 17.04.2019, https://papers.ssrn.com/abstract=3372669 (dostęp: 13.01.2021).

20 M. Przychodniak, Cyfryzacja w ChRL: transformacja gospodarki i insynieria spotecæna, PISM, 15.03.2018, https://www.pism.pl/publikacje/Cyfryzacja_w_ChRL_transformacja_gospodarki_ i_in_ynieria_spo_eczna_(dostęp: 13.01.2021).

21 Y. Xugang, R. Cristiano, T. Mario, Z. Fabio, G. Li, China's Belt and Road: The initiative and its financial focus, ,World Scientific” 2018, vol. 2, s. 65.

22 State Council, $13^{\text {th }}$ five-Year plan for national informatization, 15.04.2016, http://www.gov.cn/ zhengce/content/2016-12/27/content_5153411.htm (dostęp: 13.01.2021). 
Przez lata można było zaobserwować rozwój chińskiego sektora technologicznego na rynkach wschodzących, a niektóre z tych wysiłków dopiero niedawno zostały przypisane do projektów Cyfrowego Jedwabnego Szlaku. Xi Jinping na Drugim Forum BRI w kwietniu 2019 r. otwarcie odnosił się do współpracy w gospodarce cyfrowej i mówił o rozwoju opartym na innowacjach jako priorytetowych obszarach $\mathrm{BRI}^{23}$. Oficjalne przedstawiono, że DSR ,nie tylko promuje rozwój sektora usług cyfrowych, takich jak transgraniczny handel elektroniczny, rozwój inteligentnych miast, telemedycyny i finansów internetowych, ale także przyspiesza postęp technologiczny, w tym przetwarzania danych, możliwości Internetu, sztuczną inteligencję, blockchain i obliczeń kwantowych"24. Można także odnaleźć informacje, że zwiększanie łączności było jednym z kluczowych aspektów BRI od samego początku, ale z czasem program Cyfrowego Jedwabnego Szlaku stał się szerszy i obejmuje takie obszary, jak wzmocnienie infrastruktury internetowej (np. sieci 5G), pogłębianie współpracy kosmicznej, opracowywanie wspólnych standardów technologicznych i wiele innych ${ }^{25}$.

Informacje zawarte w chińskim raporcie politycznym pt. Postęp, wkład i perspektywy Inicjatywy Pasa i Szlaku świadczą o rozległości chińskich planów ${ }^{26}$. Chiny zdefiniowały swoje nowe podejście, próbując wykorzystać „duże zbiory danych” do rozwiązywania niektórych problemów związanych ze zrównoważonym rozwojem. Ich cyfrowa strategia jest skierowana głównie do gospodarek rozwijających się, a jej celem jest ułatwienie tym krajom łączności cyfrowej ${ }^{27}$. Współpraca w ramach Cyfrowego Jedwabnego Szlaku ma także w głównej mierze przyczynić się do: 1) transformacji gospodarczej, 2) wzmocnienia integracji regionalnej oraz 3) zapewnienia źródeł finansowania w celu wzmocnienia globalnego multilateralizmu i stabilności politycznej ${ }^{28}$. Jednakże można także wyodrębnić inne motywacje Cyfrowego Jedwabnego Szlaku, takie jak: poszerzenie działań w ramach inicjatywy Belt and Road; wdrażanie przejścia gospodarczego Chin z gospodarki opartej na produkcji do

23 Xi Jimping Chairs and Addresses the Leaders' Roundtable of the Second Belt and Road Forum for International Cooperation (BRF), Belt and Road Forum, 28.04.2019, http://www.beltandroadforum.org/ english/n100/2019/0429/c22-1392.html (dostęp: 14.01.2021).

${ }^{24}$ H. Yong, Construction of digital Silk Road lights up BRI cooperation, „People's Daily”, 24.04.2019, http://en.people.cn/n3/2019/0424/c90000-9571418.html (dostęp: 14.01.2021).

25 Deloitte, BRI Update 2019 - Recalibration and New Opportunities, https://www2.deloitte.com/ $\mathrm{cn} / \mathrm{en} / \mathrm{pages} / \mathrm{soe} /$ articles/bri-update-2019-recalibration-and-new-opportunities.html (dostęp: 14.01.2021).

26 The Belt and Road Initiative Progress, Contributions and Prospects, Belt and Road Portal, 22.04.2019, https://eng.yidaiyilu.gov.cn/zchj/qwfb/86739.htm (dostęp: 14.01.2021).

27 P. Lasak, R. Linden, The Financial Implications of China's Belt and Road Initiative. A Route to More Sustainable Economic Growth, Cham 2019, s. 89.

28 S. Deorukhkar, Le Xia, China: One Belt One Road - Progress and Prospects, BBVA Research 2017, s. 2, https://www.bbvaresearch.com/en/publicaciones/china-one-belt-one-road-progress-and-prospects/ (dostęp: 14.01.2021). 
gospodarki opartej na usługach; pomoc chińskim firmom w zwiększeniu dostępu do większego rynku zbytu; dążenie Chin do wzmocnienia integracji regionalnej poprzez rozwój infrastruktury cyfrowej; osiagnięcie przywództwa w dziedzinie nowoczesnych technologii na świecie; rozpowszechnianie chińskich norm i standardów cybernetycznych poprzez sektor IT; przyczynienie się do zrównoważonego rozwoju ekologicznego (nowoczesna infrastruktura IT pobudzi nowe rynki rozwoju np. poprzez zatrudnienie w dziedzinach, które nie generują tylu zanieczyszczeń); dążenie Chin do zapewnienia systemowi międzynarodowemu (światowemu) dodatkowego źródła finansowania, aby pobudzić globalny multilateralizm i stabilność polityczną poprzez zachęcanie do inwestycji w infrastrukturę.

W ramach Cyfrowego Jedwabnego Szlaku zainwestowano w sieci telekomunikacyjne, systemy płatności mobilnych oraz projekty, takie jak: inteligentne miasta, e-administracja, inteligentna edukacja, cyfrowa opieka zdrowotna i inne inicjatywy związane z dużymi zbiorami danych w państwach rozwijających się. Według analityków Mercator Institute for China Studies (MERICS) chińskie podmioty przekazały ponad 17 mld USD na projekty Digital Silk Road ukończone od 2013 r., w tym: co najmniej 7 mld USD pożyczek i zagranicznych inwestycji bezpośrednich na projekty kabli światłowodowych i sieci telekomunikacyjnych zakończone od 2013 r.; ponad 10 mld USD na transakcje e-commerce i płatności mobilne; na inteligentne i bezpieczne projekty miejskie przynajmniej kilkaset milionów USD ${ }^{29}$. W przypadku ośrodków danych i ośrodków badawczych dostępne informacje są zbyt ograniczone, aby dokonać oszacowania ${ }^{30}$.

Cyfrowy Jedwabny Szlak najlepiej więc rozumieć jako fundamentalny wysiłek budowania chińskiej marki i narracji w celu promowania globalnej wizji rozwoju technologicznego. Chiny podpisały już umowy o współpracy DSR z co najmniej 16 państwami lub zrealizowały inwestycje związane z inicjatywą ${ }^{31}$. Jednak prawdziwa liczba umów $i$ inwestycji jest prawdopodobnie znacznie większa, ponieważ wiele z nich nie jest zgłaszanych: protokoły ustaleń (Memorandum of Understanding) niekoniecznie wskazują, czy Chiny i inny kraj podjęły bliską współpracę w sferze cyfrowej. Niektóre szacunki sugerują, że jedna trzecia państw uczestniczących w BRI (obecnie 138) współpracuje przy projektach DSR $^{32}$. Na przykład w Afryce Chiny

29 T.S. Eder et al., Networking the 'Belt and Road' - The Future is Digital, Mercator Institute for China Studies, 28.08.2019, https://merics.org/en/analysis/networking-belt-and-road-future-digital (dostęp: 14.01.2021).

30 Ibidem.

31 S. Feldstein, Testimony before the U.S.-China Economic and Security Review Commission Hearing on China's Strategic Aims in Africa, https://www.uscc.gov/sites/default/files/Feldstein_Testimony. pdf (dostęp: 15.01.2021).

32 Ch. Jia Hao, China's Digital Silk. Road: The Integration Of Myanmar - Analysis, „Eurasia Review", 30.04.2019, https://www.eurasiareview.com/30042019-chinas-digital-silk-road-the-integration-of-myanmar-analysis/ (dostęp: 14.01.2021). 
już teraz zapewniają więcej środków finansowych na technologie informacyjne i komunikacyjne niż wszystkie agencje wielostronne i wiodące państwa demokratyczne razem wzięte na całym kontynencie ${ }^{33}$.

\section{Chińskie firmy i ich przykładowe działania w ramach Cyfrowego Jedwabnego Szlaku}

W przeciwieństwie do państwowych konglomeratów wiodących w projektach infrastrukturalnych BRI, uczestnicy DSR są zwykle chińskimi „prywatnymi” firmami technologicznymi, z mniejszym doświadczeniem w działaniu poza chronionym rynkiem Chin. Azja Południowo-Wschodnia była wczesnym i szczególnym celem chińskiej ekspansji ${ }^{34}$. Podobnie jak w przypadku projektów energetycznych i transportowych BRI, China Development Bank (CDB), Export-Import Bank of China (EXIM) i państwowe banki komercyjne zapewniły finansowania projektów zakupu chińskiego sprzętu teleinformatycznego i telekomunikacyjnego poza granicami ChRL. Na przykład indyjski operator telekomunikacyjny Bharti Airtel ${ }^{35}$ otrzymał $^{2}$ 2,5 mld USD, a rosyjski Rostelecom 600 mln USD ${ }^{36}$ częściowo na zakup sprzętu firmy Huawei i ZTE. Kolejna pożyczka ulgowa umożliwiła Huawei realizację kabla światłowodowego South Atlantic Inter Link (SAIL) o długości 6 tys. km, łączącego Kamerun z Brazylia, dla konsorcjum pod przewodnictwem China Unicom z partnerem z Kamerunu ${ }^{37}$.

W ramach działań dyplomatycznych Chiny utworzyły również inicjatywę współpracy w dziedzinie gospodarki cyfrowej z 7 innymi państwami, w tym Serbią, aspirującym członkiem $\mathrm{UE}^{38}$. Oprócz podstawowego sprzętu technologicznego chińskie firmy rozszerzyły swoją działalność o wdrażanie e-zarządzania, inteligentnych projektów edukacyjnych i cyfrowej opieki zdrowotnej. Na przykład Unia Afrykańska w 2017 r. uruchomiła inteligentny pokój monitorowania zdrowia z wykorzystaniem

33 J. Kurlantzick, J. West, Assessing China's Digital Silk Road Initiative, „Council on Foreign Relations", 7.09.2020, https://www.cfr.org/china-digital-silk-road/ (dostęp: 14.01.2021).

34 S. Ahmed, ASEAN: A Testing Ground for the Digital Silk Road, China-United States Exchange Foundation, 28.03.2018, https://www.chinausfocus.com/finance-economy/asean-a-testing-groundfor-the-digital-silk-road (dostęp: 15.01.2021).

35 H. Shein, Building a Digital Silk Road? Situating the Internet in China's Belt and Road Initiative, „International Journal of Communication” 2018, vol. 12, s. 2684.

36 M. Lennighan, Rostelecom gets $\$ 600 \mathrm{~m}$ in Chinese funding, Totaltelecom, 9.09.2015, https://www. totaltele.com/view.aspx?C=0\&ID=491046 (dostęp: 16.01.2021).

37 T. McGregor, China Breakthrougbs: SAIL ahead on South Atlantic cable network, China Central Television, 7.05.2017, http://english.cctv.com/2017/07/05/ARTITi0QntQhXqvZoN4dwobj170705.shtml (dostęp: 16.01.2021).

38 G. Yiming, Digital economy cooperation to empower Belt Road, China.org.cn, 4.12.2017, http:// www.china.org.cn/world/2017-12/04/content_50083923.htm (dostęp: 16.01.2021). 
technologii ZTE ${ }^{39}$. Chińskie firmy szukają możliwości w branży med-tech (technologie medyczne, od wyposażenia kapitałowego po biomateriały i innowacje w zakresie implantów), a także w nadzorze sztucznej inteligencji (AI). Wspierają też eksport infrastruktury i sprzętu technologicznego, oferując szkolenia w zakresie ich użytkowania i zarządzania cyberprzestrzenią ${ }^{40}$. Należy podkreślić, że nie tylko państwa autorytarne importują chińskie technologie. Przykładowo w 2019 r. australijskie miasto Darwin przyjęło platformę ,inteligentnego miasta”, a tamtejsi urzędnicy udali się do Chin, aby przejść szkolenie w zakresie jej użytkowania ${ }^{41}$.

Poniższy wykaz poszczególnych chińskich gigantów technologicznych również uwydatnia ogrom ich działań w ramach DSR.

Alibaba zainwestował 4 mld USD w internetowy rynek Lazada i posiada w niej $80 \%$ udziałów ${ }^{42}$. W zeszłym roku zainwestował 1,1 mld USD w indonezyjską firmę e-commerce Tokopedia ${ }^{43}$. Alibaba otworzył także w 2019 r. centrum danych w Japonii i Indonezji. Dostarcza usługi w chmurze, m.in. w Korei Południowej i Singapurze. Rozwija swoja platformę e-handlu - AliExpress.com, m.in. w Azji Południowo-Wschodniej i Ameryce Łacińskiej. Alibaba Cloud, która kontynuuje rozwój usług przetwarzania w chmurze za granica, ogłosiła w maju 2020 r. partnerstwo z kontrolerem inteligentnego systemu ruchu Sena Traffic Systems w celu zbudowania systemu zarządzania ruchem w Malezji. Alibaba ma ponad 22 zagraniczne centra danych poza Chinami, współpracuje również z firmą Singtel i południowokoreańską SK Group w celu świadczenia usług w chmurze.

Huawei i ZTE są ściśle zaangażowane w rozwój sieci technologii 5G na rynkach krajów trzecich. Przedstawiciele Huawei nadal odnoszą sukcesy w zdobywaniu nowych kontraktów 5G. Pomimo presji Stanów Zjednoczonych Huawei podpisał

39 E. Tankou, African Union Commission (AUC) Launches Smart Health Monitoring System, „The African Union Commission", 26.10.2017, https://au.int/en/newsevents/20171026/african-union-commission-auc-launches-smart-health-monitoring-system (dostęp: 16.01.2021).

40 A. Shahbaz, Freedom on the Net 2018: The Rise of Digital Authoritarianism, Freedom House, 12.12.2018, https://freedomhouse.org/report/freedom-net/2018/rise-digital-authoritarianism (dostęp: 16.01.2021); zob. też: J. Parkinson et al., Huawei Technicians Help African Governments Spy on Political Opponents, „Wall Street Journal”, 15.08.2019, https://www.wsj.com/articles/huawei-technicians-helped-african-governments-spy-on-political-opponents-11565793017 (dostęp: 16.01.2021).

41 Council to Return to Shenzhen for Final Assessments as Smart City Project Comes to an End, „The West Australian", 14.04.2019, https://thewest.com.au/news/nt/council-to-return-to-shenzhenfor-final-assessments-as-smart-city-project-comes-to-an-end-ng-06de2544dd5238fb4edeeb9d5e88139c (dostęp: 16.01.2021).

42 J. Russell, Lazada, Alibaba's Southeast Asia e-commerce business, gets a new CEO, „Techcrunch”, 12.12.2018, https://techcrunch.com/2018/12/12/lazada-alibabas-southeast-asia-e-commercebusiness-gets-a-new-ceo/ (dostęp: 16.01.2021).

43 M. Ruehl, H. Sender, The battle for south-east Asia's online shoppers, „Financial Times”, 8.10.2020, https://www.ft.com/content/eb264616-0eb1-4dc9-bfbe-5406f349a5fb (dostęp: 16.01.2021). 
kontrakt z Kenią na inteligentne miasta i centrum danych o wartości $175 \mathrm{mln}$ USD $^{44}$, umowę z Pakistanem na centrum danych w chmurze oraz projekt rozwoju szybkiego bezprzewodowego Internetu (głównie 4G) ${ }^{45}$. W lutym Tajlandia uruchomiła pierwsze stanowisko testowe 5G firmy Huawei w Azji Południowo-Wschodniej ${ }^{46}$. Alibaba, JD.com $\mathrm{i}$ Tencent również wyraziły zainteresowanie inwestowaniem w tym państwie. W kwietniu Huawei uruchomił laboratorium innowacji w chmurze i sztucznej inteligencji w Singapurze ${ }^{47}$. Co najmniej 80 państw z Ameryki Lacińskiej, Afryki i Azji przyjęło rozwiązania firmy Huawei, takie jak Safe City lub inne chińskie platformy nadzoru i technologii bezpieczeństwa ${ }^{48}$. Firma ta nadal prowadzi rozmowy z killkoma krajami Azji Środkowej, Azji Południowo-Wschodniej, Afryki i innymi. Większość z nich koncentruje się na rozwiązaniach z zakresu bezpieczeństwa publicznego, wykorzystujących sztuczną inteligencję i technologię nadzoru.

China Mobile na początku 2019 r. ogłosiła program pilotażowy mający na celu opracowanie sieci dróg w skali miasta, obsługującej zarówno usługi mobilne, jak i inteligentny transport w Wuhan. Do końca 2020 r. firma zobowiązała się do zainstalowania 300 tys. stacji bazowych 5G, a już w 2019 r. otworzyła centrum danych w Singapurze. Ponadto w czerwcu 2020 r. Chiny zakończyły tworzenie systemu nawigacji satelitarnej Beidou. Jest on konkurencją dla amerykańskiego systemu GPS czy europejskiego Galileo ${ }^{49}$.

Warto zwrócić uwagę na działania prywatnych firm z Chin. Jak podkreślono, Alibaba odnosi niesamowite sukcesy w Malezji, co jest odzwierciedleniem sił rynkowych i technologicznych, a nie tylko inicjatyw chińskiego rządu ${ }^{50}$. Oznacza to, że skala wyzwania wynikającego z DSR jest znacznie większa i bardziej złożona, niż gdyby wynik wynikał wyłącznie z odgórnej polityki chińskiego rządu. Widoczna

44 J. Nyabiage, Kenya says it supports Chinese tech giant Huawei regardless of US policy, SCMP, 20.12.2020, https://www.scmp.com/news/china/diplomacy/article/3114635/china-australiarelations-beijings-trade-restrictions-are (dostęp: 16.01.2021).

45 S. Moss, Huawei signs MoU with Pakistan for cloud data center, „Data Centre Dynamics”, 29.04.2019, https://www.datacenterdynamics.com/en/news/huawei-signs-mou-pakistan-clouddata-center/ (dostęp: 16.01.2021).

46 C. Helly, Huawei launches $5 G$ test bed in Thailand, Total telecom, 8.02.2019, https://www.totaltele.com/502119/Huawei-launches-5G-test-bed-in-Thailand (dostęp: 16.01.2021).

47 Huawei Launches Cloud \& AI Innovation Lab in Singapore, 25.04.2019, https://www.huawei.com/ en/news/2019/4/huawei-cloud--ai-innovation-lab-singapore (dostęp: 16.01.2021).

48 S.Ch. Greitens, Dealing with Demand for China's Global Surveillance Exports, „Brookings Institution Global China Report", April 2020, https://www.brookings.edu/research/dealing-with-demand-for-chinas-global-surveillance-exports/ (dostęp: 16.01.2021).

49 D. Wnukowski, Chiński Cyfrowy Jedwabny Szlak - znaczenie gospodarcze i polityczne, PISM, 17.11.2020, https://www.pism.pl/publikacje/Chinski_Cyfrowy_Jedwabny_Szlak_znaczenie_ gospodarcze_i_polityczne (dostęp: 16.01.2021).

50 Alibaba Cloud Continues to Invest in Malaysia, https://www.alibabacloud.com/campaign/malaysia (dostęp: 16.01.2021). 
jest w przypadku DSR rosnąca koncentracja na firmach prywatnych, a nie przedsiębiorstwach państwowych. Oczywiście nie można także zapominać o negatywnym wpływie bliskich związków chińskiego biznesu (nawet prywatnego) z chińskimi władzami. W tym kontekście warto zwrócić uwagę na interesujący artykuł autorstwa Zacha Dorfmana, w którym pisze, że prywatne chińskie firmy zostały zwerbowane do przetwarzania skradzionych danych dla państwowych agencji szpiegowskich. Autor przytacza także wypowiedź Elsy Kani, ekspertki ds. Chin i adiunkta w Center for a New American Security, która twierdzi, że „większość chińskich firm technologicznych nie różni się zbytnio od swoich odpowiedników w Dolinie Krzemowej. Różnica polega na tym, że starają się działać w systemie, w którym istnieją zachęty i oczekiwania, aby kultywować bliższe relacje z rządem" ${ }^{\text {"51. }}$.

\section{Cyfrowy Jedwabny Szlak - zalety i wyzwania}

Chiny poszerzają i pogłębiają swoje „technosfery” - obszary geograficzne, w których maja przewagę polityczna, gospodarczą oraz w zakresie gromadzenia danych i informacji dzięki eksportowi technologii i mechanizmów kontrolnych zarządzania informacjami w ramach $\mathrm{BRI}^{52}$. Te technosfery bezpośrednio dostarczają Chinom danych dotyczących tego najcenniejszego towaru, tzw. nowej ropy, czyli danych. Dzięki umowom dotyczącym Cyfrowego Jedwabnego Szlaku, wspieranym przez chiński rząd, chińskie firmy zabezpieczaja prawa do danych gromadzonych za pośrednictwem chińskiej technologii ${ }^{53}$. Trzeba mieć bowiem na uwadze, że każda firma działająca w Chinach może być prawnie zmuszona do zapewnienia władzom ChRL dostępu do zaszyfrowanych danych w imię bezpieczeństwa narodowego i wywiadu ${ }^{54}$. Partia ma więc potencjał do ich kontrolowania w dowolnym momencie, chociaż firmy te działaja na wolnym rynku. KPCh wykorzystała technologię, aby uczynić kontrolę polityczną nieodłącznym elementem rozwoju społecznego i gospodarczego Chin. W szczególności wielu zachodnich obserwatorów podkreśla

51 Z. Dorfman, Tech giants are giving china a vital edge in espionage, „Foreign Policy”, 23.12.2020, https://foreignpolicy.com/2020/12/23/china-tech-giants-process-stolen-data-spy-agencies / (dostęp: 16.01.2021).

52 V. Weber, The Worldwide Web of Chinese and Russian Information Controls, Open Technology Fund, https://public.opentech.fund/documents/English_Weber_WWW_of_Information_ Controls_Final.pdf (dostęp: 16.01.2021).

53 L. Chutel, China is Exporting Facial Recognition Software to Africa, Expanding its Vast Database, „Quartz Africa”, 25.05.2018, https://qz.com/africa/1287675/china-is-exporting-facial-recognition-to-africa-ensuring-ai-dominance-through-diversity/ (dostęp: 16.01.2021).

54 W. Turton, Hidden Back. Door Embedded in Chinese Tax Software, Firm Says, „Bloomberg”, 25.07.2020, https://www.bloomberg.com/news/articles/2020-06-25/hidden-back-door-embedded-in-chinese-tax-software-firm-says (dostęp: 16.01.2021). 
ryzyko szpiegostwa i inwigilacji płynące z chińskiego Cyfrowego Jedwabnego Szlaku. Znaczna część europejskiej debaty na temat cyfrowej strony chińskiej Inicjatywy Pasa i Szlaku koncentruje się na roli Huawei w sieciach 5G na świecie oraz na sprzedaży chińskiego sprzętu do monitoringu ${ }^{55}$. Tego typu głosy przyczyniają się do braku poczucia technologicznego bezpieczeństwa.

Budowanie globalnej sieci informacyjnej, w której centrum znajdują się Chiny, w naturalny sposób przyczyniło się do ekspansji rynkowej chińskich firm technologicznych. Chiny stają się wiodącym graczem w rozwoju cyfrowym, finansując łączność cyfrową w regionach niedostatecznie rozwiniętych. Za sprawą chińskiej oferty kraje rozwijające się zaczynaja stosować technologie cyfrowe i rozważaja przejście na sieć $5 \mathrm{G}$ nowej generacji. Zauważalne jest także to, że podobnie jak w przypadku projektów infrastrukturalnych chińskie firmy technologiczne w coraz większym stopniu dążą do współpracy z międzynarodowymi korporacjami, aby czerpać korzyści z ich międzynarodowej reputacji, technologii i doświadczenia w zarządzaniu. Cyfrowy Jedwabny Szlak kreuje więc zarówno korzyści, jak i wyzwania.

Najważniejsze zalety to:

1) atrakcyjność cenowa np. w zakresie technologii $5 G$, co może wynikać m.in. z szerokiego wsparcia finansowego chińskich banków;

2) wygoda i uproszczenie poprzez komplementarne względem siebie oferty (np. sprzętu i oprogramowania), co zapewnia kompleksowość rozwiązań;

3) przyczynianie się do rozwoju i integracji gospodarki cyfrowej z gospodarką realna, co z kolei stanowi siłę napędową rozwoju gospodarczego i społecznego;

4) umożliwianie poprawy warunków życia ludności i przyspieszanie rozwoju w krajach położonych wzdłuż inicjatywy Pasa i Szlaku poprzez zwiększenie dostępu do telekomunikacji;

5) dostarczanie dodatkowych korzyści krajom rozwijającym się poprzez tworzenie ośrodków szkoleniowych i programów badawczo-rozwojowych. Zacieśnienie współpracy między naukowcami i inżynierami w tych krajach a ich chińskimi odpowiednikami oraz transfer wiedzy technicznej w takich obszarach, jak inteligentne miasta, sztuczna inteligencja i robotyka oraz czysta energia.

Czwarta z wymienionych wyżej zalet odpowiada na potrzeby rozwojowe szczególnie biedniejszych państw. Wskaźniki przedstawione na Konferencji ONZ ds. Handlu i Rozwoju (UNCTAD), dotyczące popularyzacji internautów, ich udziału w wykorzystaniu w płatnościach kartami kredytowymi, poziomu logistyki i bezpieczeństwa serwerów, potwierdzają że średnia wartość dla państw położonych wzdłuż Inicjatywy Pasa i Szlaku osiagnęła 49\%, czyli nieco więcej niż średnia światowa wynosząca $47,2 \%$. Dane te pokazuja, że w pewnym stopniu państwa leżące

55 T. Eder, R. Arcesati, J. Mardell, Networking the "Belt and Road": The future is digital, Mercator Institute for China Studies, 28.08.2019, https://merics.org/en/analysis/networking-belt-and-road-future-digital (dostęp: 16.01.2021). 
wzdłuż realizacji tej inicjatywy mają jakieś namiastki rozwoju cyfrowego. Jeśli jednak spojrzymy już na podział regionalny, to na przykład średni udział gospodarki cyfrowej w produkcie krajowym brutto (PKB) państw z regionu Bliskiego Wschodu wynosi zaledwie 4\%. Niepokojący jest fakt, że w niektórych regionach występuje zubożała ludność, zwłaszcza ludność żyjąca poniżej granicy skrajnego ubóstwa, co rodzi ogromne ryzyko, ale budzi i nadzieję, że „rozwój oparty na danych” staje się przedmiotem zainteresowania krajów położonych wzdłuż tego projektu.

Zagrożenia i wyzwania Cyfrowego Jedwabnego Szlaku to m.in.:

1) obawy o bezpieczeństwo narodowe poszczególnych państw, np. możliwość wykorzystywania przez ChRL technologii $5 \mathrm{G}$ w celach szpiegowskich (zarzuty te podnoszą głównie USA). Szpiegostwo i przymus wobec polityki innych państw mogłyby wzrastać, gdyby Pekin wykorzystywał naruszenia danych do szantażowania tychże elit politycznych. Chiny mogą więc wykorzystać mniejsze gospodarki, wpływać na ich politykę krajową i manipulować nią ${ }^{56}$. Obawy związane z bezpieczeństwem obejmują też potencjalne zagrożenia dla infrastruktury krytycznej poszczególnych państw;

2) uchylanie się przez ChRL od przyjmowania zobowiązań dotyczących przepływu danych i ich ochrony, jak również ewentualne problemy naruszenia bezpieczeństwa państw przyjmujących mogą ograniczać rozwój DSR. Państwa muszą zachować czujność przy ustalaniu standardów oraz w odniesieniu do ochrony praw i wolności obywateli ${ }^{57}$;

3) umożliwienie krajom-odbiorcom przyjęcia modelu autorytaryzmu opartego na technologii, co byłoby szkodliwe dla wolności osobistych i suwerenności w tych państwach. Chińskie firmy technologiczne pomogły już rządom w innych krajach w opracowaniu możliwości nadzoru, które można by wykorzystać przeciwko grupom opozycyjnym, a Pekin zapewnił szkolenia dla zainteresowanych krajów-odbiorców DSR w zakresie monitorowania i cenzurowania Internetu w czasie rzeczywistym ${ }^{58}$;

4) ograniczenie chińskim firmom dostępu do amerykańskich technologii;

5) skutki pandemii, która m.in. pogorszyła sytuację finansów publicznych wielu państw, co może je skłonić do renegocjacji warunków umów.

56 B. Ly, Challenge and perspective for Digital Silk Road, Taylor \& Francis Online, 14.05.2020, https://www.tandfonline.com/doi/full/10.1080/23311975.2020.1804180 (dostęp: 16.01.2021).

57 Joint Civil Society Statement: States Use of Digital Surveillance Technologies to Fight Pandemic Must Respect Human Rights, „Human Rights Watch”, 2.05.2020, https://www.hrw.org/news/2020/04/02/ joint-civil-society-statement-states-use-digital-surveillance-technologies-fight (dostęp: 16.01.2021).

58 J. Parkinson, N. Bariyo, J. Chin, Huawei Technicians Helped African Governments Spy on Political Opponents, „The Wall Street Journal”, 15.08.2019, https://www.wsj.com/articles/huawei-technicians-helped-african-governments-spy-on-political-opponents-11565793017 (dostęp: 16.01.2021). 


\section{Technologiczna rywalizacja o sieć $5 \mathrm{G}$}

Wiele państw na świecie poprawiło swój globalny układ strategiczny dzięki konkurencyjności cyfrowej. Na przykład Stany Zjednoczone sformułowały Big Data Research and Development Initiative już w 2012 r., Wielka Brytania wprowadziła Strategię Gospodarki Cyfrowej (2015-2018), Niemcy wydały Digital Strategy 2025, Francja zaproponowała plan polityki Digital State, a Japonia opowiadała się za stworzeniem Super Smart Society ${ }^{59}$. Kraje położone wzdłuż Inicjatywy Pasa i Szlaku muszą dostosować się do tego nowoczesnego trendu, wykorzystać związane z tym możliwości, nowe narzędzia do dużych zbiorów danych, wprowadzić innowacje w sposobach alokacji zasobów i zwiększyć konkurencyjność przedsiębiorstw. Aby osiagnąć przewagę konkurencyjną $\mathrm{w}$ globalnym rozwoju przemysłowym, państwa muszą budować połączenia danych i sieci komunikacyjne oraz umożliwić przepływ informacji, aby napędzać przepływ kapitału i talentów.

Nasilenie strategicznej konkurencji między Stanami Zjednoczonymi a Chinami nadało nowy rozmach wysiłkom całego rządu Stanów Zjednoczonych na rzecz ograniczenia wykorzystania chińskiej technologii. Inicjatywy, takie jak globalna kampania przeciwko Huawei i technologii 5G, wytyczyły dalsze granice między konkurencyjnymi zachodnimi i chińskimi sferami technologicznymi. Na polityczne postrzeganie DSR wpłynęła także rozpowszechniająca się wśród zachodnich polityków narracja, że Pekin kieruje eksport chińskiego modelu „techno-autorytarnego” do krajów wzdłuż BRI. Dlatego znaczące pogorszenie stosunków między USA a Chinami $i$ konkurencja technologiczna może z czasem zmusić Chiny do podjęcia odrębnego procesu ustanawiania standardów w niektórych obszarach w porozumieniu z państwami beneficjentami BRI. Prawdopodobieństwo takiego rozwoju zdarzeń może zależeć od ewolucji pandemii koronawirusa i jej wpływu na stosunki tego państwa z USA. Cyfrowy aspekt międzynarodowego profilu Chin stał się najbardziej kontrowersyjny w następstwie obaw USA związanych z bezpieczeństwem, dotyczących wiarygodności Huawei jako dostawcy kabli światłowodowych i sieci 5G. W odpowiedzi na obawy o zagrożenia dla bezpieczeństwa Australia zapewniła tańszą alternatywę dla zastapienia chińskiej firmy technologicznej w budowie podmorskiego łącza światłowodowego z Wyspami Salomona ${ }^{60}$. W Europie Wielka Brytania i Holandia zdecydowały się ograniczyć sprzęt Huawei do innych niż podstawowe części ich sieci telekomunikacyjnych $5 \mathrm{G}^{61}$.

59 H. Liang, Y. Zhang, The Theoretical System of Belt and Road Initiative, Singapore 2019, s. 41.

60 Solomon Islands drops Chinese tech giant Huawei for billion-dollar undersea cable, signs Australia, SCMP, 13.06.2018, https://www.scmp.com/news/asia/diplomacy/article/2150616/solomon-islands-drops-chinese-tech-giant-huawei-billion-dollar (dostęp: 16.01.2021).

${ }_{61}$ M. Satake, Europe adopts Huawei gear into $5 G$ networks over US objections, „Nikkei Asia”, 16.05.2019, https://asia.nikkei.com/Spotlight/5G-networks/Europe-adopts-Huawei-gear-into5G-networks-over-US-objections (dostęp: 16.01.2021). 
Amerykańskie firmy szybko dostrzegły potencjał Cyfrowego Jedwabnego Szlaku. Wiele wiodących amerykańskich międzynarodowych koncernów technologicznych, takich jak Microsoft, IBM, Apple, Qualcomm, Intel, Cisco i Oracle, od dziesięcioleci jest uwikłanych w chińską gospodarkę cyfrową. Ich ugruntowane platformy chińskie pozwalają teraz na stosunkowo łatwy dostęp do BRI. Pomimo tego powstaje zauważalny problem - chińskie firmy technologiczne potrzebuja jeszcze większego wzrostu na rynkach rozwijających się, ponieważ są wykluczone z bogatszych państw. Stany Zjednoczone, Australia, Japonia i niektóre państwa europejskie zakazują chińskim firmom technologicznym dostępu do infrastruktury 5G. Chca ograniczenia ekspansji chińskich gigantów technologicznych. W szczególności kraje Afryki, Bliskiego Wschodu i części Europy Wschodniej, Ameryki Łacińskiej i Azji Południowo-Wschodniej potrzebuja niedrogiej, wysokiej jakości technologii do rozbudowy bezprzewodowych sieci telefonicznych i szerokopasmowego Internetu. Ogólnie przewiduje się, że światowa luka w finansowaniu infrastruktury osiagnie prawie 15 bln USD do $2040 \mathrm{r}^{62}$ Inwestycje związane z DSR mogą więc pomóc wypełnić tę lukę i pobudzić wzrost, zapewniając infrastrukturę krytyczną lub pomagając w jej finansowaniu.

\section{Podsumowanie}

W czasie pandemii COVID-19 zwiększa się nacisk Chin na rozwój sektora cyfrowego. Pandemia ukazała, że nierówności związane z przepaścią cyfrowa tj. działania oparte na wykorzystaniu sztucznej inteligencji, zdalnej pracy czy e-learningu, są niewykonalne w większości państw. Obawy dotyczące bezpieczeństwa technologii stanowią poważną przeszkodę dla chińskich producentów i dostawców, dążących do pogłębienia i poszerzenia zasięgu technologicznego DSR, który stał się centralnym punktem BRI. Trzeba podkreślić, że kontrolowanie przepływu danych staje się coraz istotniejsze dla zmiany równowagi sił geopolitycznych Chin. Pomimo potencjalnych zagrożeń zgłaszanych przez państwa rozwinięte i niektóre kraje rozwijające się Pekin zapewne będzie kontynuował swoje działania. Chiny wydały już ok. 79 mld USD na projekty związane z DSR, a ich finansowanie w tym zakresie prawdopodobnie znacznie wzrośnie. Wraz z rozwojem Cyfrowego Jedwabnego Szlaku pojawiające się wokół niego konflikty między państwami wyrażającymi wiele obaw względem tej inicjatywy a niektórymi rządami, które mogą na tym skorzystać, będą się tylko nasilać. W dłuższej perspektywie DSR nie tylko zapewni to chińskim firmom przewagę konkurencyjną, ale także umożliwi im szerszą ekspansję na in-

62 A. George, R. Kaldany, J. Losavio, The world is facing a $\$ 15$ trillion infrastructure gap by 2040. Here's how to bridge it, „World Economic Forum”, 11.04.2019, https://www.weforum.org/agenda/2019/04/infrastructure-gap-heres-how-to-solve-it/ (dostęp: 16.01.2021). 
nych rynkach. Ten aspekt może mieć znaczące implikacje zarówno dla światowej ekonomii, jak i geopolityki. Liczne projekty w ramach inicjatywy nie zostały jeszcze ukończone, a wiele porozumień o współpracy i memorandów nie zostało podpisanych lub zrealizowanych. Wpływ strategicznych chińskich wizji na gospodarkę światowa powoli się ujawnia, niemniej potrzebny jest czas, aby mogły ukazać swój prawdziwy potencjał.

\section{SUMMARY}

\section{THE DIGITAL SILK ROAD AND THE GROWING SIGNIFICANCE OF THE PEOPLE'S REPUBLIC OF CHINA IN THE COMPETITION OVER TECHNOLOGICAL SUPREMACY IN THE WORLD}

Over the past few years, many scientists have analyzed China's Belt and Road Initiative, but very few have studied a significant component of this initiative - the Digital Silk Road (DSR). Although the attention regarding the implementation of the Belt and Road initiative is focused mainly on the implementation of international transport infrastructure projects, such as roads, railways or ports, it seems important to pay attention to the technological component of this project. The main goal of the article is to present the most comprehensive information possible on the Digital Silk Road and to investigate Chinese activities in this area. It should be emphasized that the early stage of development, namely the planning of the Belt and Road Initiative, as well as the Digital Silk Road, raises many scientific questions, such as: what is the Digital Silk Road? What actions have been taken to implement it? What challenges and threats can it generate? Will the Digital Silk Road contribute to an even greater exposure - the technological, growing role of China in the world? Undoubtedly, the Digital Silk Road, which is a platform promoting the development of digital connections between the countries participating in the initiative, can help spread Chinese digital "inventions - products." In addition, it may contribute to facilitating the economic and social development of the countries along the initiative, thus improving the level of economic development of the beneficiary countries and generating new international competitive advantages. The Digital Silk Road is an inherent requirement for building China's digital power in the world, and therefore a current and very important research area. The work on this article uses desk research on the changing position of the People's Republic of China in the competition for technological leadership in the world, as well as the consequences it entails. 